Arab World English Journal (AWEJ) Special Issue on Covid 19 Challenges April 2021

DOI: https://dx.doi.org/10.24093/awej/covid.15

\title{
Virtual Mini-Lecture in Distance Learning Space
}

\author{
Olena Palatovska \\ Department of Russian Language and Literature, Faculty of Slavic Philology, \\ Kyiv National Linguistic University (KNLU), Kyiv, Ukraine
}

\begin{abstract}
Mariana Bondar
Department of Russian Language and Literature, Faculty of Slavic Philology, Kyiv National Linguistic University (KNLU), Kyiv, Ukraine
\end{abstract}

\begin{abstract}
Olga Syniavska
Department of Russian Language and Literature, Faculty of Slavic Philology, Kyiv National Linguistic University (KNLU), Kyiv, Ukraine Corresponding Author: olga.sinyavskaya1989@gmail.com
\end{abstract}

\section{Oleksandr Muntian}

Department of Russian Language and Literature, Faculty of Slavic Philology, Kyiv National Linguistic University (KNLU), Kyiv, Ukraine

Received: $2 / 21 / 2021$

Accepted: 4/3/2021

Published: 4/26/2021

\begin{abstract}
The COVID-19 pandemic has fundamentally affected all the spheres of human life, including education. Universities worldwide have established distance learning, which demanded combining and improving both traditional and innovative education forms. The article offers a comprehensive analysis of pre-recorded mini-lectures in the educational space of distance learningfor different scientific-educational Internet projects (Coursera, PostNauka, Udacity, edX, LinguaLeo, EdEra, etc.). Mini-lectures are complete pieces of speech limited in time and accessible to multiple reproductions; that is why they are quite a representative material for the research of the generation of cognitive processes and perception of a verbal educational message in asynchronous online learning. The significant results of the study include: the definition of invariable characteristics of virtual mini-lectures (distance, virtuality, mediation, situational incorrigibility, multimodality), defining cognitive strategies of the speaker and the listener in an asynchronous lecture interaction, finding the points of contact (motivation and interest in transferring and receiving information) between them. The article also describes the linguistic features of virtual mini-lecture. These conclusions can find practical application in the development of methodology for the distance teaching of linguistic disciplines.

Keywords: asynchronous online learning, cognitive strategies, distance learning, invariable characteristics, lecture interaction, scientific-educational discourse, virtual mini-lecture

Cite as: Palatovska, O., Bondar, M., Syniavska, O., \& Muntian, O. (2021). Virtual Mini-Lecture in Distance Learning Space. Arab World English Journal (AWEJ) Special Issue on Covid 19 Challenges (1) 199-208. DOI: https://dx.doi.org/10.24093/awej/covid.15
\end{abstract}


Arab World English Journal (AWEJ) Special Issue on Covid 19 Challenges April 2021

Virtual Mini-Lecture in Distance Learning Space

Palatovska, Bondar, Syniavska \& Muntian

\section{Introduction}

The SARS-CoV2 pandemic has radically changed the life of the whole world. It has introduced adjustments to all spheres of activity of the world community, including the higher education system. Universities around the world had to take up distance education, and consequently, educational programs changed, as well as educational technologies and evaluation systems. The vital part of the educational process, the paradigm of communication between teacher and student, has changed too.

Since the 1990s, computer-mediated communication has become a new reality for various discourse practices, including the scientific-educational discourse, the World Wide Web offers unprecedented opportunities for access to scientific and educational online resources. Internet users can have distance learning and professional training. They use the web for individual development and self-education. Internet repositories of scientific and educational information are very diverse - electronic versions of traditional scientific and popular periodicals, textbooks, monographs, dictionaries, various scientific and educational multimedia portals, individual and group communication of specialized scientific-educational Internet projects, e-mail, chats, thematic forums, etc. Language is the mediator between a separate person and "megaknowledge" concentrated on the Internet. At the same time, the importance of the language is growing drastically, and the language itself is going through significant changes. The Internet offers the opportunity of multimodal receiving of information using the whole complex of external perceptional stimuli - verbal, prosodic, and visual, which causes a kind of erasure of boundaries between the oral and written modes of communication and, respectively, to the increase of the role of an oral form of receiving information (Valigura, Kozub \& Sieriakova, 2020). It causes the increased interest of researchers towards functional-pragmatic aspects of language activity in the virtual space of the Internet, related to the peculiarities of perception, structuring, storage and transmission of knowledge in new conditions. Researchers study the issues of generation and adequate perception of oral texts of scientific-educational character and the causes of successful scientific, educational, and business communication (Crystal, 2001; Herring, 2004).

Online learning can be classified into two groups - synchronous and asynchronous, depending on the nature of Internet facilities. Synchronous learning is the simultaneous interaction of a teacher and students from different locations. Asynchronous learning involves indirect communication between the teacher and students. The teacher offers students pre-loaded materials and instructions and, if necessary, gives them feedback, evaluates their work (Bailey, Almusharraf \& Hatcher, 2020; Clark, 2015).

This paper offers a comprehensive analysis of pre-recorded mini-lectures in the educational space of asynchronous learning. Despite the evident advantages (mobility, globality, relative cheapness, the absence of territorial limits, shorter time and physical expenses), the attitude towards asynchronous receiving knowledge through the Internet among the world scientific-pedagogical society is ambiguous: psychologists, teachers, sociologists, and linguists have repeatedly mentioned the "mosaic", chaotic, superficial character of this way of receiving educational information, and the formation of the new type of thinking - clip thinking - within the youth (Carr, 2010; Chernigovskaya, 2013; Girenok, 2016; Kuznetsova, 2015). Still, getting an education and further professional training on the Internet actively continues to evolve and get 


\section{Arab World English Journal (AWEJ) Special Issue on Covid 19 Challenges April 2021}

Virtual Mini-Lecture in Distance Learning Space

Palatovska, Bondar, Syniavska \& Muntian

more and more advocates. COVID-19 has accelerated this process; it made scientific methodologists and practical teachers direct their efforts not only on criticism of distance learning but also on its development and improvement (Astleitner, 2020).

The video lectures of famous specialists in various spheres of knowledge have been growing in popularity. These lectures are available on various scientific and educational Internet portals Coursera, PostNauka, Udacity, edX, LinguaLeo, EdEra, etc. The leading universities are partners of these sites. Research organizations from different countries of the world contribute to them. Their users are, as a rule, educated people who need additional knowledge in a particular field of activity, and people interested in self-improvement.

The person who receives scientific-educational information in the virtual space of the Internet can learn according to one's schedule, in the time free from their primary employment and be independent of the location, following various goals - both pragmatic and simply informative. At the same time, the practice of distance learning has revealed some limitations. When the user can choose the time for receiving knowledge on the Internet, they are likely to fail to get organized and perceive information long-term, for various reasons. People with clip thinking, as a rule, are not able to concentrate for a long time; they remember only the information that interests them at the present moment. They need additional visual effects for attention support. Therefore, short lecture video materials are becoming one of the leading methods in distance online education, we can call the mini-lectures.

The aimsof this article are the systematization and interpretation of the invariable characteristics of a virtual mini-lecture, and the description of the cognitive strategies of the speaker and listener in the online processes of generation and perception of lecture information in successful communication. The article discusses the issues related to increasing the motivation of students in the context of distance education. It outlines theoretical approaches to the study of an asynchronous virtual mini-lecture, and outlines the essential components of the structure of joint attention of the speaker and listener, which are necessary for successful asynchronous lecture interaction.

\section{Literature Review}

In pedagogics and psychology, the issue of distance learning has been researched for quite along time. The main factor influencing the fact that the students who start online learning break it up more frequently than they do with traditional education isinsufficient oral, visual and emotional contact with the teachers and the other students (Bartley \& Golek, 2004; Thompson, 1997). The student life suggests not only learning but also personal emotional communication, full participation in the social life of the university. The educational activity takes place in a broad social and cultural context. Keller (1997) has suggested bringing the model of instructional design model over into the distance learning space; he offered this model earlier, and it consists of the following components: Attention - Relevance - Confidence - Satisfaction (ARCS), aimed at the motivation increase among the learners. This model has been successfully used and modified in the other studies on increasing motivation in distance education (Visser, 1998).

Tomasello (2008) presented a five-step model of successful human communication, consisting: 1) the joint intention of the speaker and listener for successful communication; 2) the 
joint attention of the communication participants; 3) general prosocial motives; 4) common assumptions (and even norms) of cooperation between participants; 5) shared human language conventions. (Tomasello, 2008, p. 107-108). Compliance with all of these components is difficult, so the responsibility for the successful learning communication lies on both the teacher and the student.Shared knowledge and the ability to share the intentions of other people in the learning process are the primary conditions of human communication.For successful communication in real life, besides the direct knowledge of the language system in which the communication takes place, the whole complex of other knowledge and skills is needed: motivation, turning to the previous experience and memory, developed attention and imagination, the consideration of the addressee factor, the awareness of the existing limitations and the correct use of various communication strategies in different communication situations, the timely switching between the verbal and non-verbal culture codes, in other words for the productive generation and perception of language signs in verbal communication the so-called "accomplice cooperation" is necessary (Tomasello, 2008, p. 72). When the speaker produces text, he expects the listener to understand it. It is aimed at a kind of influence on the listener: to form new ideas about an event or a phenomenon of reality; to influence their emotional condition or call to a specific action, etc.

When the addressee perceives the audial message, he tries to forecast the purposes and attitudes of the speaker, foresee the intention of the utterance, and activate his knowledge on the topic of speech in his consciousness. The quality of a communicative interaction depends on both the extralinguistic and linguistic components.

This way, to perform successful and effective communication, the individuals taking part in it, no matter what their roles are (the speaker or the listener), are active subjects. Recent neurobiological research has proven this fact and has shown that the generation and perception of verbal messages are tightly linked and are practically mirror processes about each other. The group of neurobiologists in Princeton University, researching the links between the brain areas of the speaker and the listener in the process of natural communication employing magnetic resonance imaging, have concluded "that average the speaker's production-based processes precede and likely induce the mirrored activity observed in the listener's brains during comprehension" (Stephens, Silbert \& Hasson, 2010, p. 3). They also established that although the brain activity of the listener mirrors the brain activity of the speaker with an unavoidable delay, some listeners show preemptive reactions towards the perceived information. With such connections between the speaker and the listener, the understandingbecomes easier (Stephens et al., 2010). These connections are essential when perceiving educational information asynchronously.

\section{Methods}

The present study fully represents the newest interdisciplinary approach to analyzing the issues of methodology and methods of foreign language learning. During the investigation of virtual mini-lectures considering cognitive strategies of the speaker and the listener, we used a whole range of research methods: general scientific and traditional linguistic methods (observation, induction and deduction, generalization, collation, and description) provided for the revealing and the definition of regularities of generation and perception of verbal scientificeducational messages in online way, systematization, and interpretation of the functional 


\section{Arab World English Journal (AWEJ) Special Issue on Covid 19 Challenges April 2021}

peculiarities of language units in the vocal mode of scientific communication. The cognitive discourse method of research has united the procedures of discourse and cognitive analyses directed from the discourse towards the linguistic units that form it.

The actual research materials are oral mini-lectures on linguistics and cognitive sciences from various educational Internet portals (Coursera, PostNauka, LingLing, etc.), which led to the following results.

\section{Results}

A pre-recorded mini-lecture on the Internet is video performance containing logically coherent theoretical material, which lasts between 10 and 40 minutes. An online mini-lecture is gradually becoming an independent genre which is growing in popularity. Within the sociolinguistic approach, it is a kind of scientific-educational institutional discourse. According to the information channel, it is to actively develop computer-mediated Internet communication.

The invariable characteristics of a virtual mini-lecture are:

- distance and virtuality, i.e., the independence from space-time coordinates;

- mediation and situational incorrigibility, i.e., the absence of immediate feedback between the participants of communication which is always present in synchronous communication;

- multimodality of the acts of transmission and receiving of information which consists in uniting the audial, visual, and prosodic signals;

- possibility of multiple reproductions by the user.

Any linguistic activity suggests the presence of two active subjects: the speaker and the listener. They perform generation and perception of information. The cognitive strategies of the participants in a communicative act are inextricably linked but at the same time they differ significantly from each other.

These differences are particularly distinctly actualized in the processes of distance communication. With the absence of the immediate feedback characteristic of traditional lecture interaction, the active role of the addressee of the message is more distinct along with the uncontrolled perception of the information by the addressee. When we look at the characteristics of asynchronous virtual communication (a mini-lecture), it is necessary to point out the speaker's and the listener's positions. They define cognitive strategies. Seeing the intersection points between them is needed for successful communication.

The listener of a virtual pre-recorded mini-lecture:

- is as a rule motivated, interested, and ready to perceive complicated information, as every Internet user can decide on their own which information is of interest to them;

- is independent of space-time coordinates, although the virtual reality can imitate the "effect of presence" at the lecture in the space relation for them; 


\section{Arab World English Journal (AWEJ) Special Issue on Covid 19 Challenges April 2021}

- can reproduce mini-lecture many times to achieve an understanding of the material, and at the same time, they can use hypertext and interactive Internet capabilities for the independent search of necessary materials on the topic of the lecture;

- can remain anonymous, if desired.

Anonymity will help listeners feel free and independent, to criticize indirectly, to ask questions, and to communicate with the authors of the lecture. Users can also share with the other site users in the chat and commentaries to the watched material.

The speaker (author) of a mini-lecture:

- is oriented towards a sufficiently educated, motivated, and interested listener, and still, while the social certification of the audience in the virtual space of the Internet is only presumptive, they need to simplify the text delivery of the information both in the content and in the choice of linguistic means for its embodiment;

- is dependent on the space-time coordinates: the listener listens to the recording of a mini-lecture here and now, and the speaker must fit in its time format set for this or that educational-informative portal;

- combines the pre-thought content filling of the lecture with the improvisation of its verbal embodiment in online mode, as a rule, producing the verbal message without relying upon the previously written text;

- is always personalized (the anticipatory comments usually contain sufficient data about the lecturer and their sphere of research interests: the academic degree and title, the place of work, the list of scientific works on the topic of the lecture, and the other necessary information which should interest the user and motivate them for the perception of the lecture material).

Listening to a pre-recorded mini-lecture on the Internet, the same as a usual lecture with the immediate contact between the subjects of lecture interaction, the listener perceives it through three information channels - verbal, prosodic, and visual, and the virtual reality of the Internet imitates the effect of the unique presence. The main peculiarity and the difference of a virtual mini-lecture from its traditional analog for the listener lie in the opportunity of its multiple reproductions, due to which they achieve a possibility to reach the understanding of the necessary material. However, it may be difficult to estimate the correctness of the understood material because of the absence of feedback with the lecturer.

The communication is successful for the addressee if he is readily interested and motivated to receive necessary information. High communicative competence and the rhetoric mastery of the lecturer are also crucial for the addressee.

The speaker doesn't receive feedback from the communicative partners at all. He cannot see his audience; it is anonymous. The author of a mini-lecture cannot verify if the assimilation of the learning material is in progress because there is no immediate contact with the listeners. Consequently, a good orator should think over the volume and the content of the information input and take care of the accessibility of the linguistic means. The speaker should pay great 


\section{Arab World English Journal (AWEJ) Special Issue on Covid 19 Challenges April 2021}

attention not only to the choice of vocabulary and grammar but also to the speed of the narration, the intonation, pauses, and the use of paralinguistic means.

In the dynamic process of speech generation in online mode, the author of a mini-lecture is put in the condition of time limits, that is why constant control over one's speech is crucial: the elimination of ambiguities, the differentiation between the main and the secondary, providing the text coherence. All this brings to the appearance of various kinds of hesitations, corrections, rearrangement of syntax in the course of speaking, the unplanned change of the text structure, etc., in oral speech.

In the biosocial approach to language characteristics of contemporary cognitive linguistics and methodology, the abovementioned speech failures in oral communication are not a deviation from the norm but rather a natural characteristic of oral discourse. As a whole, they do not reduce the quality of the sounding speech. The repetitions, pleonasm, syntactic parallelism, the duplication of referential forms (the Noun / the Pronoun), syntactic priming, the presence of discourse markers (such as especially, well, so, I think, it is clear, it is essential, etc.), etc. typical for the oral discourse organization, consolidate the effort of the speaker and the listener in the shared communicative process. This facilitates the process of generation of an oral utterance by the addresser of the message, and at the same time the restoration of the meaning of the uttered material in the process of the perception by the addressee.

We can conclude that, despite the absence of immediate contact between the participants of a virtual pre-recorded mini-lecture, the "joint attentional frame" (Tomasello, 2008, p. 74) still exists between the addresser and the addressee of the scientific-educational message - without it, successful communication would be impossible. This genre wouldn't have become so popular in the virtual Internet space. Such psychological factors as motivation and interest in conveying and receiving information unite the participants of the lecture interaction, as well as Internet technologies that provide multimodal presentation of the information and the option of multiple listening to a mini-lecture, which allows alleviating its perception. The communicative competence of the speaker provides the linguistic characteristics of a virtual mini-lecture directly ensuring the transfer of new knowledge to the listener. Minimization of the content of the represented learning material and the inevitable simplification of grammar structures and the shortening of the number of the used terms, the linguistic redundancy, and recursiveness allow not to lose the sense of the presented material. To anchor the heard in the consciousness of the listener, - all this works for the adequate perception and understanding of the necessary educational information (see Figure 1).

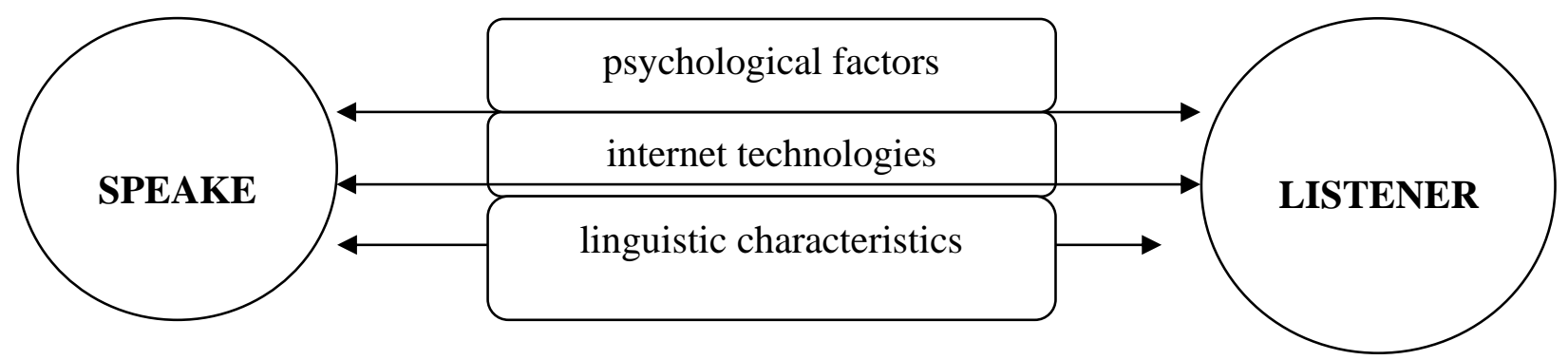

Figure 1. Communicative interface SPEAKER $\leftrightarrow$ LISTENER 
Arab World English Journal (AWEJ) Special Issue on Covid 19 Challenges April 2021

Virtual Mini-Lecture in Distance Learning Space

Palatovska, Bondar, Syniavska \& Muntian

\title{
Discussion
}

The tension caused by the virus SARS-CoV2 is global, and it generates anxiety about the quality and level of higher education in the world society. Methodologists and practical teachers strive to optimize the educational process as much as possible based on synchronous and asynchronous distance education. Virtual pre-recorded mini-lectures are increasingly used on various educational platforms, and their effectiveness is becoming more and more prominent (D’Lima, 2020; Li, Guo \& Han, 2018). Also, virtual mini-lectures are quite a representative material for the research of cognitive processes of generation and perception of oral educational messages in the online mode, the linguistic components of this genre of scientific-educational communication, and its optimization in the conditions of distance learning. Mini-lectures are complete pieces of speech limited in time and accessible for multiple reproductions, and, as a result, they are helpful as theoretical and experimental material for research.

According to sociologists, most teachers and students would like to go back to the traditional form of education. But it is becoming clear that after the pandemic, society will not fully return to intramural education. Most probably, it will be a mixture of classical education forms with the newest digital designs. A reasonable combination of traditional and innovative technologies in the space of distance learning can be a fairly successful step towards the education of future generations.

\section{Conclusion}

The present article aimed to observe a virtual mini-lecture as a new genre of oral academic communication in the space of distance learning. In the course of our research, we identified the invariable characteristics of this genre. We have defined the peculiarities of its language design and possible intersection points of the participants of lecture interaction. We have studied the cognitive and discourse positions of the speaker and the listener in successful communication.

The new genre of scientific-educational discourse studied in the article is a virtual minilecture. It provides a quiterepresentational language material for the research of the functions, peculiarities, and new forms of language use in cognitive processes of knowledge acquisition, organization, and storage, and transferring it to other users of innovational virtual communication. These conclusions can find practical application in methodology development for the distance teaching of linguistic disciplines while preparing lectures, tutorials, and functional grammars in digital format, including those for the students learning the English language as a non-native language. By teaching, we learnourselves.

\begin{abstract}
About the Authors:
Olena Palatovska, Doctor of Science (Philology), Associate Professor, Head of the Department of Russian Language and Literature, Faculty of Slavic Philology, Kyiv National Linguistic University, Ukraine. Research interests: cognitive linguistics, discourse analysis, complex sentence syntax, cross-cultural studies, foreign language teaching.

ORCID ID: https://orcid.org/0000-0002-6084-6505
\end{abstract}

Mariana Bondar, Ph.D. in Philology, Associate Professor at the Department of Russian Language and Literature, Faculty of Slavic Philology, Kyiv National Linguistic University, 
Arab World English Journal (AWEJ) Special Issue on Covid 19 Challenges April 2021

Virtual Mini-Lecture in Distance Learning Space

Palatovska, Bondar, Syniavska \& Muntian

Ukraine. Research interests: theory and practice of translation, intercultural communication, turkish studies, foreign language teaching. ORCID ID: https://orcid.org/0000-0002-2463-6308

Olga Syniavska, Ph.D. in Philology, Associate Professor at the Department of Russian Language and Literature, Faculty of Slavic Philology, Kyiv National Linguistic University, Ukraine. Research interests: mass-media communication, cognitive linguistics, onomasiology, foreign language teaching. ORCID ID: https://orcid.org/0000-0002-3241-1854

Oleksandr Muntian, Ph.D. in Philology, Associate Professor at the Department of Russian Language and Literature, Dean of the Faculty of Slavic Philology, Kyiv National Linguistic University, Ukraine. Research interests: historical linguistics, Russian studies, cross-cultural studies, foreign language teaching. ORCID ID: https://orcid.org/0000-0002-7004-0249

\section{References}

Astleitner, H. (2020). Alternative theoretical frameworks for educational interventions. In H. Astleitner, (Ed.), Intervention research in educational practice (pp. 19-37). Münster, New York: Waxmann.

Bailey, D., Almusharraf, N. \& Hatcher, R. (2020). Finding satisfaction: intrinsic motivation for synchronous and asynchronous communication in the online language learning context. Educ Inf Technol. https://doi.org/10.1007/s10639-020-10369-z

Bartley, S. J. \& Golek, J. H. (2004). Evaluating the cost-effectiveness of online and face-to-face instruction. Educational Technology \& Society, 7 (4), 167-175.

Carr, A. N. (2010). The Web Shatters Focus, Rewires Brains. Wired. http://www.wired.com/2010/05/ff_nicholas_carr/all/1

Chernigovskaya, T. V. (2013). Distributed consciousness. http://theoryandpractice.ru/posts/7582-chernigovskaya/

Clark, C. (2015). Comparing Asynchronous and Synchronous Video versus Text-Based Discussions in an Online Teacher Education Course. http://dx.doi.org/10.24059/olj.v19i3.510

Crystal, D. (2001). Language and the Internet. Cambridge: Cambridge University Press.

D'Lima, D. (2020). 'Chunking' lectures into shorter, meaningful recordings for online delivery. https://www.ucl.ac.uk/teaching-learning/case-studies/2020/oct/chunking-lectures-shortermeaningful-recordings-online-delivery

Girenok, F. I. (2016). Clip consciousness: clips in science, clips in philosophy, clips in politics, clips in art, clips in education, non-clip. Moscow: Prospect.

Herring, S. C. (2004). Computer-mediated discourse analysis: An Approach to Researching Online Behavior. In S. A. Barab, R. Kling, \& J. H. Gray (Eds.), Designing for Virtual Communities in the Service of Learning (pp. 338-376). New York: Cambridge University Press.

Keller, J. M. (1997). Motivational design and multimedia: Beyond the novelty effect. Strategic Human Resource Development Review, 1 (1), 188-203.

Kuznetsova, O. V. (2015). Distance learning: pro and contra. International Journal of Applied and Basic Research, 8 (II), 362-364.

Li L., Guo R.\& Han M. (2018). On-Demand Virtual Lectures: Promoting Active Learning in Distance Learning. Publication. ICEBT: Proceedings of the 2nd International Conference 
Arab World English Journal (AWEJ) Special Issue on Covid 19 Challenges April 2021

on E-Education, E-Business and E-Technology, 1-5. https://doi.org/10.1145/3241748.3241757

Singh, R. N. \& Hurley, D. (2017). The Effectiveness of Teaching-Learning Process in Online Education as Perceived by University Faculty and Instructional Technology

Professionals. Journal of Teaching and Learning with Technology, 6 (1), 65-75.

Stephens, G., Silbert, L. \& Hasson, U. (2010). Speaker-listener neural coupling underlies successful communication. Proceedings of National Academy of Sciences of the United States of America, 10 7(32), 1442514430.https://www.ncbi.nlm.nih.gov/pmc/articles/PMC2922522/

Thompson, E. (1997). Distance education drop-out: What can we do? http://cleo.murdoch.edu.au/asu/pubs/tlf/tlf97/thom324.html

Tomasello, M. (2008). Origins of human communication. Cambridge, MA: The MIT Press.

Valigura, O., Kozub, L. \& Sieriakova, I. (2020). Computer Technologies in Acoustic Analysis of English Television Advertising Discourse. Arab World English Journal (AWEJ) Special Issue on CALL (6), 38-48. https://dx.doi.org/10.24093/awej/call6.3

Visser, L. (1998). The development of motivational communication in distance education support. Thesis University of Twente, Enschede. 